\title{
Quality of life and osteomuscular symptoms in workers of primary health care
}

\author{
Qualidade de vida e sintomas osteomusculares em trabalhadores da atenção primária \\ Calidad de vida y síntomas osteomusculares en trabajadores de la atención primaria
}

João Roberto Cordioli Junior' ORCID: 0000-0002-9938-8687

Dezolina Franciele Cardin Cordioli' ORCID: 0000-0002-8268-122X

Claudia Eli Gazetta' ORCID: 0000-0002-2603-8803

Albertina Gomes da Silva' ORCID: 0000-0002-4813-7845

Luciano Garcia Lourenção" ORCID: 0000-0002-1240-4702

'Faculdade de Medicina de São José do Rio Preto. São José do Rio Preto, São Paulo, Brazil. "Universidade Federal do Rio Grande. Rio Grande, Rio Grande do Sul, Brazil.

How to cite this article: Cordioli Junior JR, Cordioli DFC, Gazetta CE, Silva AG, Lourenção LG. Quality of life and osteomuscular symptoms in workers of primary health care.

Rev Bras Enferm. 2020;73(5):e20190054. doi: http://dx.doi.org/10.1590/0034-7167-2019-0054

Corresponding author:

Luciano Garcia Lourenção

E-mail: lucianolourencao.enf@gmail.com

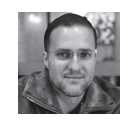

EDITOR IN CHIEF: Dulce Aparecida Barbosa ASSOCIATE EDITOR: Hugo Fernandes

Submission: 01-26-2019

Approval: 10-06-2019

\begin{abstract}
Objectives: to evaluate the quality of life and musculoskeletal symptoms in primary care workers. Methods: descriptive, correlational and cross-sectional study with 85 workers using the WHOQOL-Bref and Nordic Osteomuscular Symptoms Questionnaire. Results: lower quality of life for the Environment domain and higher for Social Relationships. Workers reported pain in lower back, neck, shoulders, wrists/hands/fingers and knees. Neck pain influenced Physical $(p=0.015)$ and Psychological $(p=0.030)$ domains; shoulder pain $(p=0.004)$ and dorsal region ( $p=0.013$ ) influenced the Physical domain; pain in knees influenced Physical $(p=0.000)$ and Environment $(p=0.032)$ domains; pain in the ankles/feet influenced Physical $(p=0.000)$, Psychological $(p=0.032)$ and Environment $(p=0.007)$ domains; pain in the dorsal region influenced the Physical domain ( $p=0.013$ ). Conclusions: workers evaluated their quality of life as good or very good and reported to be satisfied or very satisfied with their health. They also reported pains in lower back, neck, shoulders, wrists/hands/fingers and knees. Pain has influenced the quality of life.
\end{abstract}

Descriptors: Primary Health Care; Family Health Strategy; Health Personnel; Quality of Life; Cumulative Trauma Disorders.

\section{RESUMO}

Objetivos: avaliar qualidade de vida e sintomas osteomusculares em trabalhadores da atenção primária. Métodos: estudo descritivo, correlacional e transversal com 85 trabalhadores, utilizando o WHOQOL-Bref e Questionário Nórdico de Sintomas Osteomusculares. Resultados: menor qualidade de vida para domínio Meio Ambiente e maior, para Relações Sociais. Trabalhadores referiram dores na lombar, pescoço, ombros, punhos/mãos/dedos e joelhos. Dor no pescoço influenciou domínios Físico $(p=0,015)$ e Psicológico $(p=0,030)$; dor nos ombros $(p=0,004)$ e região dorsal $(p=0,013)$ influenciaram domínio Físico; dor nos joelhos influenciou domínios Físico $(p=0,000)$ e Meio Ambiente $(p=0,032)$; dor nos tornozelos/pés influenciou domínios Físico $(p=0,000)$, Psicológico $(p=0,032)$ e Meio Ambiente $(p=0,007)$; dor na região dorsal influenciou domínio Físico $(p=0,013)$. Conclusões: trabalhadores avaliaram qualidade de vida como boa ou muito boa e referiram-se satisfeitos ou muito satisfeitos com a saúde; referiram dores na região lombar, pescoço, ombros, punhos/mãos/dedos e joelhos. A dor influenciou a qualidade de vida.

Descritores: Atenção Primária à Saúde; Estratégia Saúde da Família; Pessoal de Saúde; Qualidade de Vida; Transtornos Traumáticos Cumulativos.

\section{RESUMEN}

Objetivos: evaluar la calidad de vida y síntomas osteomusculares en trabajadores de atención primaria. Métodos: investigación descriptiva, correlacional y transversal con 85 trabajadores, utilizando el WHOQOL-Bref y el Cuestionario Nórdico de Síntomas Osteomusculares. Resultados: menor calidad de vida para dominio Medio Ambiente y mayor para Relaciones Sociales. Trabajadores indicaron dolor en región lumbar, cuello, hombros, puños/manos/dedos y rodillas. El dolor en cuello influenció los dominios Físicos $(p=0,015)$ y Psicológico $(p=0,030)$; dolor en hombros $(p=0,004)$ y región dorsal $(p=0,013)$ influenció el dominio Físico; dolor en rodillas influenció los dominios Físicos $(p=0,000)$ y Medio Ambiente $(p=0,032)$; dolor en tobillos/pies influenció los dominios Físicos $(p=0,000)$, Psicológico $(p=0,032)$ y Medio Ambiente $(p=0,007)$; dolor en región dorsal influenció el dominio Físico $(p=0,013)$. Conclusiones: trabajadores evaluaron calidad de vida como buena o muy buena y se refirieron satisfechos o muy satisfechos con salud. También indicaron dolor en región lumbar, cuello, hombros, puños/manos/dedos y rodillas. El dolor influenció la calidad de vida.

Descriptores: Atención Primaria de Salud; Estrategia de Salud Familiar; Personal de Salud; Calidad de Vida; Trastornos Traumáticos Acumulativos. 


\section{INTRODUCTION}

Given the need for transformation of health services and the view of an integrated care model instead of individualized care, in the last decades, the Ministry of Health has established several initiatives aimed at modifying the health care model, including the expansion of coverage by the Family Health Strategy (FHS), creation of the National Policy of Primary Care, and Family Health Support Centers (Portuguese acronym: NASF) ${ }^{(1-3)}$.

However, the various situations of stress and dissatisfaction of Primary Health Care (PHC) workers perceived in different professional categories ${ }^{(4-5)}$ point to the little attention to their own health conditions. In fact, since PHC units are the main gateway to the Unified Health System (Brazilian SUS), these are stressful environments for health teams and users ${ }^{(6)}$.

In addition, the way professionals perform their work or the way it is imposed on them can trigger musculoskeletal morbidity. When work is performed in a strenuous manner, without pauses, repetitive and stereotyped movements and incorrect postures, symptoms appear without specific clinical entity, but with aspects related to pain, paraesthesia, fatigue, loss of strength and range of movement ${ }^{(7)}$.

These musculoskeletal morbidities include disorders of muscles, tendons, synovias (joint lining), nerves, fascias (muscle sheath) and ligaments, isolated or combined, with or without tissue degeneration. They are characterized by the occurrence of concomitant symptoms or not, such as pain, paraesthesia, heaviness and fatigue ${ }^{(8-9)}$, and are among the most common health-related problems that can cause disability in health professionals, compromise their quality of life and the care provided to health service users ${ }^{(8-10)}$.

The quality of life is the way people perceive themselves in life, socially and culturally in relation to their expectations and goals ${ }^{(11)}$. This expression has been referred to both the individuals' moment of life in society and their moments of work, since there is no way to dissociate life from work ${ }^{(12)}$.

In the workplace, quality of life involves the physical, technological, psychological and social dimensions of work that correspond to the values of a more humane and healthier organization, and relate to workers' satisfaction in a safe, mutually respectful work environment, where they have opportunities to perform their duties ${ }^{(12)}$.

For the satisfactory achievement of quality of life within this context, it is essential to value workers and their participation in decision-making, to encourage their creative potential and satisfy their needs. Moreover, there must be humanization of work relationships and improvement of working conditions ${ }^{(12-13)}$.

A study of PHC workers identified that quality of life at work can be positively and negatively affected by factors such as the professional's overload, service infrastructure, professional autonomy, job satisfaction, interpersonal relationships and team work ${ }^{(14)}$.

When seeking to determine the prevalence of musculoskeletal pain and injuries reported by nurses and nursing assistants, in a literature review study with 132 articles published in English, was identified a high prevalence of musculoskeletal pain in the lower back, followed by shoulders and neck. However, the authors emphasized a concentration of studies in hospital settings ${ }^{(10)}$.
In a study with hospital nurses in Iran, was identified a high prevalence of musculoskeletal pain in the lower back (40.0\%), neck (31.1\%), upper back (23.0\%) and knees (20.0\%) $)^{(15)}$. In a study with PHC nurses in Portugal, was identified a high prevalence of musculoskeletal symptoms in the previous 12 months (89.0\%). The most affected body region was the lower back (63.1\%), followed by the cervical region, dorsal, shoulders and wrist/hand ${ }^{(16)}$.

Given the high workloads related to occupational health problems and the few studies with $\mathrm{PHC}$ professionals, this study can contribute to develop and implement solid strategies for interventions for health and work-related quality of life of $\mathrm{PHC}$ professionals.

\section{OBJECTIVES}

To evaluate the quality of life and musculoskeletal symptoms among primary health care workers in a small municipality in the inlands of São Paulo.

\section{METHODS}

\section{Ethical aspects}

Prior to data collection, the study was approved by the Research Ethics Committee of the School of Medicine of São José do Rio Preto.

\section{Design, place of study and period}

Quantitative, descriptive, correlational and cross-sectional study, conducted in the municipality of Adamantina, state of São Paulo, in 2017 with 85 workers from Primary Health Care units.

\section{Population or sample; inclusion and exclusion criteria}

The study population consisted of all workers ( 21 physicians, 24 nurses, 30 nursing assistants/technicians, 44 community health agents, 11 dentists and 20 vector control agents) from the seven Primary Health Care units of the municipality. Professionals who were on vacation during the data collection period and/or away from professional activities for any other reason were excluded.

The study sample was defined by convenience and consisted of 85 professionals who participated in the study by answering the instruments. These professionals were nine (42.8\%) doctors, 15 (62.5\%) nurses, 12 (40.0\%) assistants / nursing technicians, 29 $(65.5 \%)$ community health agents, five (45.5\%) dentists, and 15 (75.0\%) vector control agents.

\section{Study protocol}

Data collection was performed with three self-applicable instruments. One was developed by the researchers with closed questions about training, age, sex, marital status, income, education, if the professional is satisfied and/or has already considered giving up the profession/position. The second was the abbreviated version of the WHO Quality of Life Assessment Instrument (WHOQOL-Bref) ${ }^{(17)}$ that consists of 26 questions, out of which 
two are general, one refers to life and the other to health. The remaining 24 questions are related to the Physical, Psychological, Social Relationships and Environment domains, and their respective facets. The third instrument was the Nordic Musculoskeletal Questionnaire (NMQ), which was translated, adapted and validated in Brazil ${ }^{(18)}$. It is used in the assessment of pain symptoms on neck, shoulder, elbow, forearm, wrist/hand/finger, dorsal region, lower back, hip/thigh, knee, ankle/foot in the seven previous days and the 12 previous months. It allows the evaluation of symptoms of musculoskeletal morbidity and its relationship with demographic and occupational variables, and personal habits ${ }^{(18)}$.

Data collection was scheduled with nurses of the health units and held during the team meeting. After the researchers explained the objectives of the study, workers who accepted to participate were asked to sign the Informed Consent form. Soon after, the questionnaires were given to all professionals, and after completion, they were deposited in an unidentified brown envelope for the preservation of respondents' anonymity. As some professionals did not want to answer the questionnaires at that time, researchers scheduled a date to return and receive the answered instruments (in approximately one week).

\section{Analysis of results statistics}

Data analysis was performed using the SPSS version 20.0. Sociodemographic data were used to characterize the study population. For the analysis of quality of life, were used the following calculation and analysis procedures: frequencies and descriptive statistical measures for the general questions regarding the life and health of individuals studied (How would you rate your quality of life? How satisfied are you with your health?), mean scores and standard deviations, coefficient of variation, minimum and maximum values and amplitude for each domain. Average scores were used for the facets that make up the WHOQOL-Bref domains.

The evaluation of symptoms of musculoskeletal disorders was performed by calculating the frequency of complaints presented by professionals in the seven previous days and 12 previous months.

The comparison of quality of life scores between professionals with or without symptoms of musculoskeletal disorders was performed through the $\mathrm{F}$ test in the analysis of variance (ANOVA) by considering a significance level of $95 \%(p<0.05)$.

Although PHC workers suffer different workloads according to the occupations and activities they perform, given the sample size, the results of quality of life and musculoskeletal symptoms were not analyzed by professional category. A general analysis of the sample was performed to present a global diagnosis of these aspects among PHC workers of a small municipality.

\section{RESULTS}

There were 85 workers from Family Health Teams of the municipality, out of which 29 community health agents (34.1\%), 15 vector control agents (17.6\%), 15 nurses (17.6\%), 12 nursing assistants/technicians (14.1\%), nine physicians (10.6\%) and five dentists (5.9\%). The municipality does not have the position of oral health assistant/technician, hence there was no participation of these professionals in the study.
There was a prevalence of female workers (72.6\%), married (60.0\%), 40 years of age or older (45.9\%) and income of two to five minimum wages (67.1\%). Regarding education, 28 (33.3\%) workers had complete high school and 39 (45.9\%) had higher education; 69 (81.2\%) were public servants (passed the concourse) and 62 (72.9\%) worked 40 hours per week. Workers' time in $\mathrm{PHC}$ ranged from four months to 33 years, with a median of four years and four months.

As shown in Table 1, 63 (74.1\%) workers rated their quality of life (question 1) as good or very good and 54 (63.6\%) reported being satisfied or very satisfied with their health (question 2). Furthermore, 17 (20.0\%) workers reported to be dissatisfied or very dissatisfied with their health. These results draw attention to the health conditions and quality of life of the workers studied, especially when considering that 17 (20.0\%) workers consider their health as "neither bad nor good" and 14 (16.5\%) reported to be neither satisfied nor dissatisfied with their health.

In the WHOQOL-Bref domain analysis, the mean domain scores ranged from 61.1 to 71.3 (Figure 1). The lowest score (61.1) was for the Environment domain, composed of the facets: Physical safety and security; Home environment; Financial resources; Health and social care: accessibility and quality; Opportunities for acquiring new information and skills; Participation in and opportunities for recreation/leisure activities; Physical environment: pollution, noise, traffic and climate; Transport. The highest score obtained (71.3) refers to the Social Relationships domain, composed of the facets: Personal Relationships; Social support; Sexual activity.

Table 1 - Frequency of responses of Primary Health Care workers and mean scores for general questions of quality of life, Adamantina, São Paulo, Brazil, 2017-2018, $(n=85)$

\begin{tabular}{llcc}
\hline Question & Answer options & $\mathbf{n}$ & $\%$ \\
\hline \multirow{2}{*}{ How would you rate } & 1-very bad & - & - \\
your quality of life? & 2-bad & 5 & 5.9 \\
& 3-neither bad nor good & 17 & 20.0 \\
& 4-good & 54 & 63.5 \\
& 5-very good & 9 & 10.6 \\
& Mean score & 3,8 & \\
& Standard deviation & 0,7 & \\
How satisfied are you & 1-very dissatisfied & 2 & 2.4 \\
with your health? & 2-dissatisfied & 15 & 17.6 \\
& 3-neither satisfied nor dissatisfied & 14 & 16.5 \\
& 4-satisfied & 44 & 51.8 \\
& 5-very satisfied & 10 & 11.8 \\
& Mean score & 3,5 & \\
& Standard deviation & 1,0 & \\
\hline
\end{tabular}

Figure 2 shows the mean scores for the WHOQOL-Bref domain facets. Workers presented impairment in the facets Pain and discomfort, Dependence on medicinal substances and medical aids, Negative feelings and Financial resources, which had the mean scores of 27.1, 32.2, 35.9 and 47.9, respectively. The facets Recreation and leisure (51.2), Physical environment (59.4) and New information and skills (59.5) obtained scores close to the minimum threshold thereby showing that there is some impairment of these aspects of workers' quality of life.

Regarding musculoskeletal symptoms, the main body parts where workers reported pain were the lower back, neck, shoulders, wrists/hands/fingers and knees, as shown in Figure 3. 


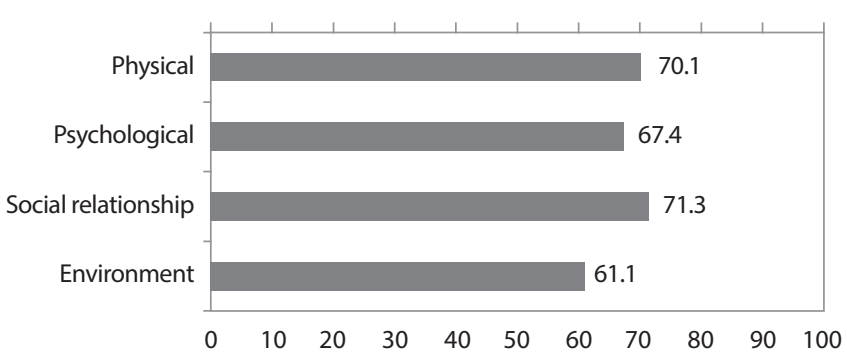

Figure 1 - Mean scores for WHOQOL-Bref domains according to Primary Health Care workers' assessment, Adamantina, São Paulo, Brazil, 20172018, $(n=85)$

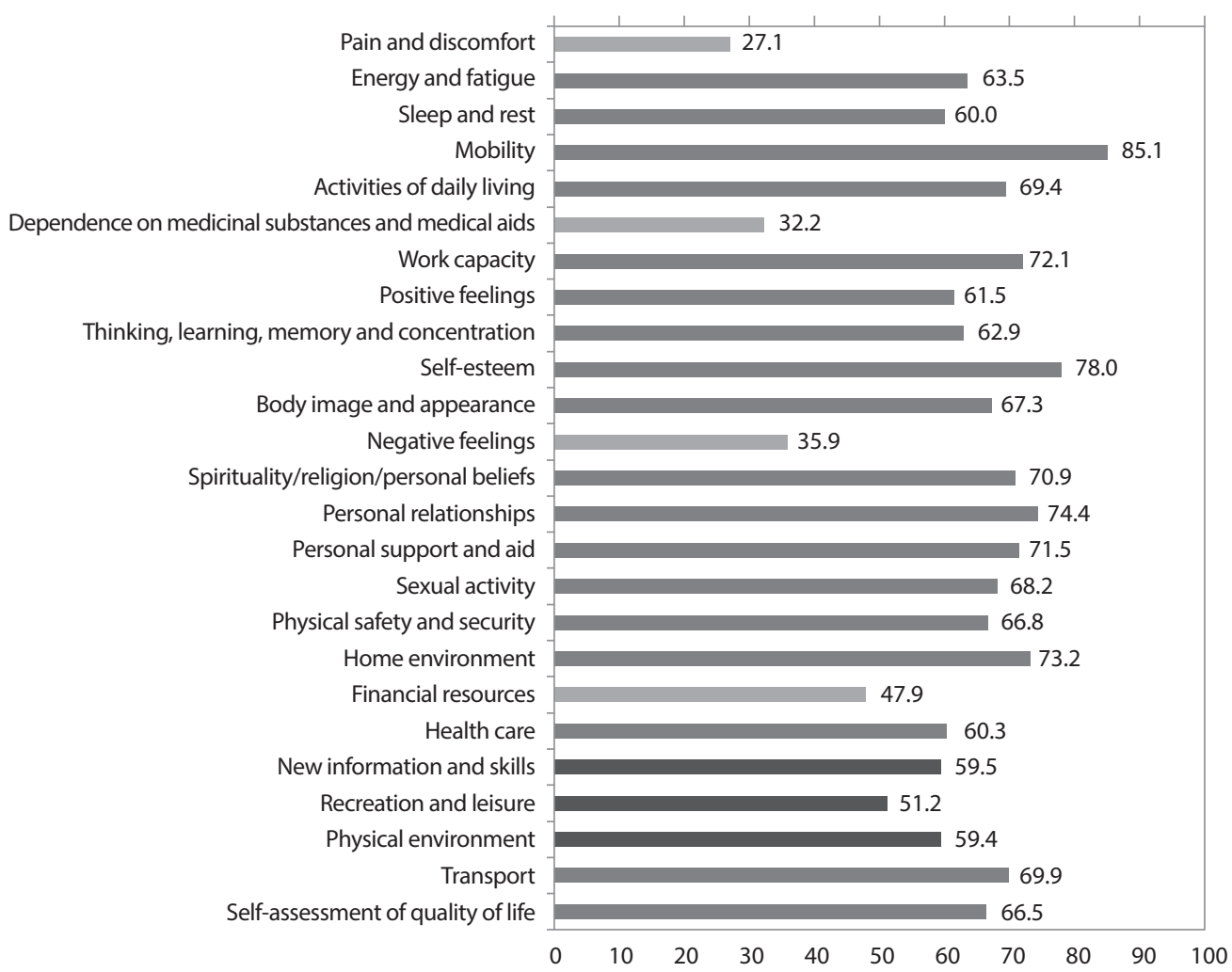

Figure 2 - Mean scores for the WHOQOL-Bref domain facets according to Primary Health Care workers' assessment, Adamantina, São Paulo, Brazil, 2017-2018, ( $\mathrm{n}=85)$

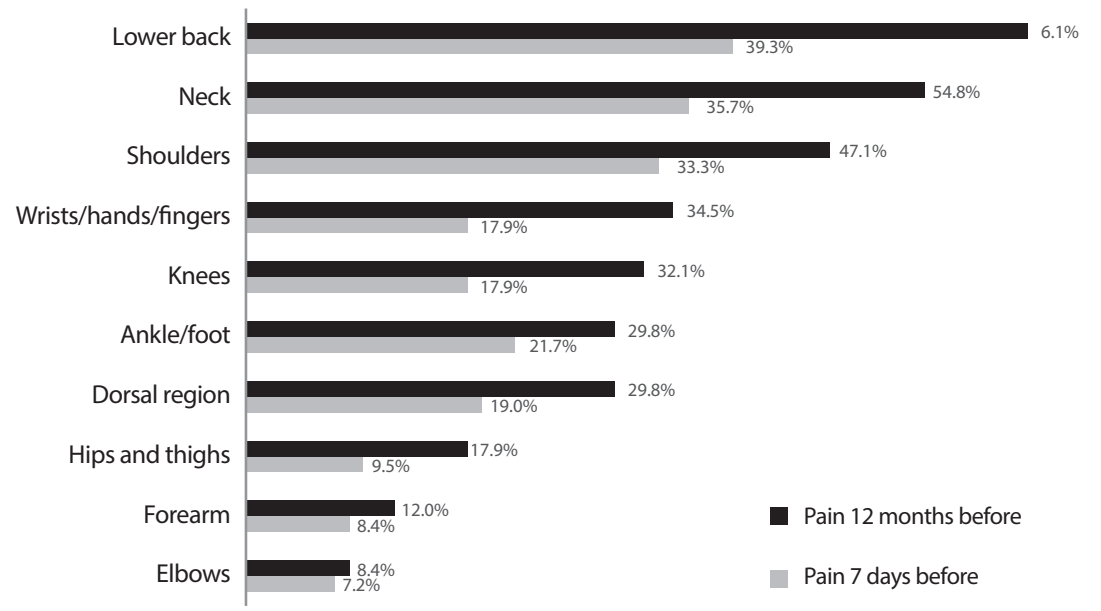

Figure 3 - Distribution of symptoms of musculoskeletal disorders in Primary Health Care workers, Adamantina, São Paulo, Brazil, 2017-2018, $(n=85)$
As shown in Table 2, the presence of neck pain influenced the quality of life in the Physical $(p=0.015)$ and Psychological $(p=0.030)$ domains; shoulder pain $(\mathrm{p}=0.004)$ and dorsal pain $(\mathrm{p}=0.013)$ influenced the Physical domain; knee pain influenced the Physical $(p=0.000)$ and Environment $(\mathrm{p}=0.032)$ domains; ankle/foot pain influenced the Physical $(p=0.000)$, Psychological $(p=0.032)$ and Environment $(0.007)$ domains; and dorsal pain influenced the Physical domain $(p=0.013)$.

\section{DISCUSSION}

The profile of workers in this study - female, married, aged 40 years or older, complete high school education, weekly workload of 40 hours, family income of two to five minimum wages, length of work in PHC from three to ten years and satisfied with the profession/ job position - is similar to other Brazilian studies with PHC professionals. A study conducted in the city of Juazeiro, state of Bahia, with community health agents found a prevalence of $81.4 \%$ of female workers, $51.7 \%$ up to 40 years old and $77.9 \%$ satisfied or very satisfied with the work capacity ${ }^{(19)}$. Similarly, national and international studies with PHC nurses showed a higher number of women in the age range of 30 to 40 years ${ }^{(16,20-21)}$. In Uberaba, Minas Gerais, over $93.0 \%$ of the community health workers studied were women with a mean age of 37.26 years $^{(22)}$.

Most workers in this study rated their quality of life as good or very good, said they were satisfied or very satisfied with their health and had better quality of life scores in the Social Relationships domain. These results may be related to the performance of their duties and the good social life of the team, which corroborates a study with $\mathrm{CHA}$ in the semiarid region of Bahia that found a high prevalence of professionals satisfied or very satisfied with their work capacity ${ }^{(19)}$.

On the other hand, the lower scores obtained in the Environment domain and in the facets Pain and discomfort, Dependence on medicinal substances and medical aids, Negative feelings and Financial resources show the negative influence 
Table 2 - Comparison of quality of life domains with presence of musculoskeletal symptoms in Primary Health Care workers, Adamantina, São Paulo, Brazil, 2017-2018, $(n=85)$

\begin{tabular}{|c|c|c|c|c|c|c|c|c|}
\hline \multirow{2}{*}{ Pain region } & \multicolumn{2}{|c|}{ Physical } & \multicolumn{2}{|c|}{ Psychological } & \multicolumn{2}{|c|}{ Social Relationships } & \multicolumn{2}{|c|}{ Environment } \\
\hline & $\mathbf{F}$ & $p$ value & $\mathbf{F}$ & $p$ value & $\mathbf{F}$ & $p$ value & $\mathbf{F}$ & $p$ value \\
\hline Lower back & 2.383 & 0.126 & 1.866 & 0.176 & 2.257 & 0.137 & 0.982 & 0.325 \\
\hline Neck & 6.230 & 0.015 & 4.863 & 0.030 & 0.453 & 0.503 & 1.186 & 0.279 \\
\hline Shoulders & 4.258 & 0.004 & 1.933 & 0.113 & 0.422 & 0.793 & 0.757 & 0.556 \\
\hline Wrists/hands/fingers & 2.381 & 0.059 & 2.327 & 0.063 & 0.836 & 0.506 & 1.666 & 0.166 \\
\hline Knees & 13.692 & 0.000 & 3.814 & 0.054 & 1.230 & 0.271 & 4.784 & 0.032 \\
\hline Ankles/Foot & 16.247 & 0.000 & 4.783 & 0.032 & 3.790 & 0.055 & 7.753 & 0.007 \\
\hline Dorsal region & 6.507 & 0.013 & 2.739 & 0.102 & 1.011 & 0.318 & 2.361 & 0.128 \\
\hline Hips and thighs & 2.877 & 0.094 & 0.033 & 0.856 & 0.009 & 0.925 & 0.033 & 0.857 \\
\hline Forearm & 1.686 & 0.177 & 0.687 & 0.563 & 0791 & 0.502 & 0.440 & 0.725 \\
\hline Elbows & 1.167 & 0.328 & 0.555 & 0.646 & 0.201 & 0.896 & 0.259 & 0.854 \\
\hline
\end{tabular}

of these aspects on workers' quality of life, and the commitment of professionals' health conditions. According to the literature, there is a relationship between low perceptions of QOL with low educational level, poor housing conditions, low income, compromised health and personal relationship difficulties ${ }^{(23)}$.

The proximity of the minimum threshold (50.0) observed in the mean scores of Recreation and leisure, Physical environment and New information and skills corroborates the results of a study on the quality of life of professionals working in the Family Health Strategy (FHS) of a municipality in the inlands of the state of São Paulo. The authors identified that although the overall quality of life was considered good by FHS professionals, when analyzing the Physical, Psychological, Social Relationships and Environment domains, the professionals showed impaired quality of life, which can affect the relationship with family, coworkers, and system users ${ }^{(13)}$.

The lack of investments in the health system interferes with the working conditions, leisure and culture of professionals and directly affects their $\mathrm{QOL}^{(23)}$. Since PHC services are responsible for promoting the health of the population, if they are poorly structured and/or poorly managed, the result can be workers' psychological and physical harm, and compromised development of users' health actions, effectiveness and resolutivity.

Therefore, managers must implement actions for workers' health care and promote health and quality of life for the prevention of stress and illness ${ }^{(13)}$. The work planning should allow the interaction and dialogue between the FHS team and other support workers of the unit by deconstructing the division of labor and professional devaluation ${ }^{(24)}$.

Pain in the lower back, neck, shoulders, wrists/hands/fingers and knees reported by the workers in this study corroborates the results found in a study with Brazilian ${ }^{(21)}$, Portuguese ${ }^{(16)}$ and Iranian $^{(15)}$ nurses, and shows the susceptibility of these professionals to develop musculoskeletal problems. In Teresina, state of Piauí, dental surgeons of PHC showed a prevalence of musculoskeletal pain in the upper limbs, lower limbs and dorsal face associated with daily and weekly work hours, fatigue and professionals' work capacity ${ }^{(25)}$.

Generally, these symptoms are caused by strenuous work activities without breaks, repetitive and stereotyped movements and incorrect postures. They appear without specific clinical entity, but with aspects related to pain, paraesthesia, fatigue, loss of strength and range of motion ${ }^{(26)}$.
As observed in this study, the presence of musculoskeletal symptoms may influence workers' quality of life, which corroborates the literature.

A study on the health conditions and quality of life of primary care professionals in Rio Grande do Sul showed that $60.0 \%$ of professionals reported physical pain and musculoskeletal problems that resulted in physical and emotional exhaustion and compromised quality of life. In addition, for $72.0 \%$ of professionals, work influences their health and quality of life and $62.0 \%$ reported that their health condition influences their work performance in primary care ${ }^{(27)}$.

In Minas Gerais, a study with CHA showed that $83.0 \%$ of professionals had musculoskeletal symptoms in the seven previous days and $93.6 \%$ in the prior 12 months. Professionals reported impaired quality of life in aspects related to the Physical (pain, general health), Psychological (vitality, mental health, emotional aspects) and Social Relationships (social aspects) dimensions that compromised their functional capacity ${ }^{(22)}$.

The results of this study reinforce that the work management model in the FHS, which is characterized by the division of labor between team members, repeated tasks and lack of communication between professionals, added to the lack of human and material resources to perform activities, exerts impact on workers health and $\mathrm{QOL}^{(14,28)}$.

Thus, given the structural, political-managerial and cultural weaknesses in the Brazilian PHC system, it is part of the municipal managers' role to implement actions of valorization of workers that promote professionals' health and quality of life, and contribute to strengthen the work management, thereby improving the effectiveness and increasing the resolutivity of services ${ }^{(29-30)}$.

\section{Study limitations}

Conducting the study in a single municipality brings limitations to the analysis of results. The sample size did not allow further analysis of results by professional category, i.e., it was not possible to further discuss the association between quality of life and musculoskeletal symptoms according to the specificities of each professional category. Therefore, the suggestion to conduct new studies with the inclusion of municipalities from different regions and a higher number of $\mathrm{PHC}$ workers thereby allowing deeper analyzes and discussions on this subject according to the particularities of each professional category. 


\section{Contributions to the area of nursing and public health}

The study provides important information about the presence of musculoskeletal symptoms among primary health care workers, who often do not consider these are harmful to their health and quality of life, because they see such symptoms as inherent to their work activities. In this sense, it contributes to Public Health by identifying the problem, allowing discussion and reflection on health care policies of these workers in order to prevent illness and impairment of health care activities provided to the population. These results are key for nursing, given the importance of these professionals for Family Health teams, and contribute to nurses, because they can think about risk prevention strategies that compromise the health of FHS workers, especially nursing professionals and CHAs, who are directly under the nurse's supervision.

\section{CONCLUSIONS}

The study showed a prevalence of female workers, aged 40 years or older, who rated their quality of life as good or very good and reported being satisfied or very satisfied with their health.

The lowest quality of life score was for the Environment domain and the highest was for the Social Relationships domain. The main body parts where workers reported having pain were lower back, neck, shoulders, wrists/hands/fingers and knees.

The presence of neck pain influenced the quality of life in Physical and Psychological domains; pain in the shoulders and dorsal region influenced the Physical domain; knee pain influenced Physical and Environment domains; ankle/foot pain influenced Physical, Psychological and Environment domains; pain in the dorsal region influenced the Physical domain.

The study contributes with the targeting of strategies for health promotion and disease prevention in the workplace and with the implementation of treatment and rehabilitation actions for workers.

The study identifies the presence of factors in the workplace that compromise workers' health and quality of life. Future investigations with broader samples will allow the expansion of knowledge about the problem and favor the targeting of health care policies for PHC workers.

\section{REFERENCES}

1. Ministério da Saúde (BR). Portaria no 2.436, de 21 de setembro de 2017. Diário Oficial da União [Internet]. 2017 [cited 2019 Apr 15];1:68. Available from: http://pesquisa.in.gov.br/imprensa/jsp/visualiza/index.jsp?data=22/09/2017\&jornal=1\&pagina=68\&totalArquivos=120

2. Arantes LJ, Shimizu HE, Merchán-Hamann E. The benefits and challenges of the Family Health Strategy in Brazilian Primary Health care: a literature review. Cien Saude Colet [Internet]. 2016 [cited 2019 Apr 15];21:1499-1509. Available from: http://www.scielo.br/pdf/csc/v21n5/ en_1413-8123-csc-21-05-1499.pdf

3. Leite DG, Souza MC, Maximino DAFM, Bezerra EP, Oliveira Filho JS, Virgínio NA et al. The Family Health Support Core (NASF) and health practices: are there many challenges to be overcome? Int Arch Med. 2017;10(106):1-9. doi: 10.3823/2376

4. Nunes MAP, Santana VR, Reis FP, Machado Neto J, Lima SO. Burnout syndrome in professionals of the primary healthcare network in Aracaju, Brazil. Cien Saude Colet [Internet]. 2015 [cited 2019 Jul 24];20(10):3011-20. Available from: http://www.scielo.br/pdf/csc/v20n10/en_14138123-csc-20-10-3011.pdf

5. Lourenção LG. Quality of life, engagement, anxiety and depression among health unit managers of Primary Care Units. Rev Port Enferm Saúde Mental [Internet]. 2018 [cited 2019 Apr 15];20:58-64. Available from: http://www.scielo.mec.pt/pdf/rpesm/n20/n20a08.pdf

6. Leonelli LB, Andreoni S, Martins P, Kozasa EH, Salvo VL, Sopezki D, et al. Perceived stress among Primary Health Care Professionals in Brazil. Rev Bras Epidemiol [Internet]. 2017 [cited 2019 Apr 15];20(2):286-98. Available from: http://www.scielo.br/pdf/rbepid/v20n2/en_1980-5497rbepid-20-02-00286.pdf

7. Santos, KOB, Almeida MMC, Gazerdin DDS. Back pain and work-related functional disabilities: records from the Notifiable Diseases Information System (SINAN/DATASUS). Rev Bras Saúde Ocup [Internet]. 2016 [cited 2018 Mar 30];41:e3. Available from: http://www.scielo. br/pdf/rbso/v41/en_2317-6369-rbso-41-e3.pdf

8. Portela NLC, Ross JR. Work-related musculoskeletal disorders (MSD) and their association with working conditions of Nursing. Rev Enferm UFPI. 2015;4(4):82-7. doi: 10.26694/reufpi.v4i4.2754

9. Lourenção LG, Sanches NF, Todesco TN, Soler ZASG. Complaints of osteomuscular problems in enhancement and improvements in a teaching hospital. Rev Enferm UFPE [Internet]. 2017 [cited 2019 Apr 15];11(Supl.1):383-92. Available from: https://periodicos.ufpe.br/ revistas/revistaenfermagem/article/view/11919/14413

10. Davis KG, Kotowski SE. Prevalence of musculoskeletal disorders for nurses in hospitals, long-term care facilities, and home health care: a comprehensive review. Hum Factors. 2015;57(5):754-92. doi: 10.1177/0018720815581933

11. Freire MN, Costa ER. Nurses' quality of life at the workplace. Rev Enferm Contemp. 2016;5(1):151-8. doi: 10.17267/2317-3378rec.v5i1.871

12. Souza DJ, Ferreira MBG, Félix MMS, Contim D, Simões ALA. Characterization of the work context and quality of life of family health strategy professionals. Cogitare Enferm. [Internet]. 2015 [cited 2019 Apr 15];20(3):562-8. Available from: https://revistas.ufpr.br/cogitare/article/ view/41124/26197.

13. Gomes MFP, Mendes ES, Fracolli LA. Quality of life of family health strategy professionals. Rev Aten Saúde [Internet]. 2016 [cited 2019 Jul 24];14(49):27-33. Available from: http://seer.uscs.edu.br/index.php/revista_ciencias_saude/article/view/3695 
14. Teles MAB, Barbosa MR, Vargas AMD, Gomes VE, Ferreira EF, Lima AMEB, et al. Psychosocial work conditions and quality of life among primary health care employees: a cross sectional study. Health Qual Life Outcomes. 2014;12(1):1-12. doi: 10.1186/1477-7525-12-72

15. Taghinejad H, Azadi A, Suhrabi Z, Sayedinia M. Musculoskeletal Disorders and Their Related Risk Factors Among Iranian Nurses. Biotech Health Sci. 2016;3(1):e34473. Available from: https://pdfs.semanticscholar.org/8d11/729f1452cea6ca155df7c5ea8922692c5764.pdf.

16. Master TR, Serranheira F, Loureiro H. Work related musculoskeletal disorders in primary health care nurses. Appl Nurs Res. 2017;33:72-7. doi: 10.1016/j.apnr.2016.09.003

17. Fleck MPA, Louzada S, Xavier M, Chachamovich E, Vieira G, Santos L et al. Application of the Portuguese version of the abbreviated instrument of quality life WHOQOL-bref. Rev. saúde pública. 2000;34(2):178-183. doi: 10.1590/S0034-89102000000200012

18. Pinheiro FA, Tróccoli BT, Carvalho CV. [Validity of the Nordic Musculoskeletal Questionnaire as morbidity measurement tool]. Rev Saúde Pública. 2002;36(3):307-12. doi: 10.1590/S0034-89102002000300008 Portuguese.

19. Castro TA, Davoglio RS, Nascimento AAJ, Santos KJS, Coelho GMP, Lima KSB. Community Health Agents: sociodemographic profile, employment and satisfaction with work in a city of Bahia's semiarid. Cad Saúde Colet. 2017;25(3):294-301. doi: 10.1590/1414-462×201700030190

20. Lorenz VR, Sabino MO, Correa Filho HR. Professional exhaustion, quality and intentions among family health nurses. Rev Bras Enferm. 2018;71(Suppl 5):2295-301. [Thematic Issue: Mental health]. doi: 10.1590/0034-7167-2016-0510

21. Oliveira JD, Ferreira AM, Moura ARG, Sousa MNA. Prevalence of self-reported musculoskeletal disorders by family health strategy nurses. Rev COOPEX/FIP [Internet]. 2017 [cited 2018 Jun 14];8(8):1-14. Available from: http://coopex.fiponline.edu.br/pdf/cliente=3-ff8ff7d76e3a45162e e38e9967e66271.pdf

22. Paula IR, Marcacine PR, Castro SS, Walsh IAP. Work ability, musculoskeletal symptoms and quality of life among community health workers in Uberaba, Minas Gerais, Brazil. Saúde Soc. [Internet]. 2015 [cited 2018 Jul 14];24(1):152-64. Available from: http://www.scielo.br/pdf/sausoc/ v24n1/en_0104-1290-sausoc-24-1-0152.pdf.

23. Almeida-Brasil CC, Silveira MR, Silva KR, Lima MG, Faria CDCM, Cardoso CL, et al. Quality of life and associated characteristics: application of WHOQOL-BREF in the context of Primary Health Care. Ciênc Saúde Colet [Internet]. 2017 [cited 2018 Jul 14];22(5):1705-16. Available from: http://www.scielo.br/pdf/csc/v22n5/en_1413-8123-csc-22-05-1705.pdf

24. Viegas SMF, Penna CMM. [The dimensions of the comprehensiveness on healthcare within the routine of the Family Health Strategy in the Jequitinhonha Valley, Minas Gerais, Brazil]. Interface (Botucatu, Online). 2015 [cited 2019 Apr 15];19(55):1089-100. doi: https://doi. org/10.1590/1807-57622014.0275 Portuguese.

25. Silva RNS, Silva JMN. Prevalence of musculoskeletal pain in primary care dentists. Rev Dor . 2017;18(3):225-31. Available from: doi: 10.5935/1806-0013.20170106

26. Dosea GS, Oliveira CCC, Lima, SO. Perception of quality of life in patients with work-related musculoskeletal disorders. Ciênc Cuid Saúde. 2016;15(3):482-8. doi: 10.4025/cienccuidsaude.v15i3.29157

27. Medeiros PA, Silva LC, Amarante IM, Cardoso VG, Mensch KM, Naman M et al. Health Status of Primary Healthcare Professionals from Santa Maria, RS, Brazil. Rev Bras Ciênc Saúde [Internet]. 2016 [cited 2018 Jul 14];20(2):115-22. Available from: https://periodicos.ufpb.br/ojs/index. $\mathrm{php} / \mathrm{rbcs} /$ article/view/18961/15739

28. Marques ALN, Ferreira MBG, Duarte JMG, Costa NS, Haas VJ, Simões ALA. Quality of life and working context of nursing professionals of the Family Health Strategy. Rev Rene [Internet]. 2015 [cited 2019 Apr 15];16(5):672-81. Available from: http://periodicos.ufc.br/rene/article/view/2794/2168

29. Seidl H, Vieira SP, Fausto MCR, Lima RCD, Gagno J. Labor management in Primary Health Care: an analysis from the perspective of PMAQAB participating teams. Saúde Debate [Internet]. 2014 [cited 2018 Jul 14];38(esp):94-108. Available from: http://www.scielo.br/pdf/sdeb/ v38nspe/0103-1104-sdeb-38-spe-0094.pdf

30. Souza RF, Abrahão AL. Reflection on the work process in the Family Health Strategy (ESF in portuguese). Rev Labor. 2017;1(3):82-95. doi: 10.29148/labor.v1i3.9291 